\title{
Sustainable Land-Use, Wildfires, and Evolving Local Contexts in a Mediterranean Country, 2000-2015
}

\author{
Maurizio Marchi ${ }^{1}$, Francesco Chianucci ${ }^{2}$ (D), Carlotta Ferrara ${ }^{1}$, Giorgio Pontuale ${ }^{1, *}$, \\ Elisa Pontuale ${ }^{1}$, Anastasios Mavrakis ${ }^{3}$, Nathan Morrow ${ }^{4}\left(\mathbb{D}\right.$, Fabrizio Rossi ${ }^{5}$ and Luca Salvati ${ }^{1}$ \\ 1 Consiglio per la Ricerca in Agricoltura e 1'Analisi dell'Economia Agraria (CREA)-Research Centre for \\ Forestry and Woods, Via Santa Margherita 80, I-52100 Arezzo, Italy; maurizio.marchi@crea.gov.it (M.M.); \\ carlotta.ferrara@crea.gov.it (C.F.); pellie18@gmail.com (E.P.); luca.salvati@crea.gov.it (L.S.) \\ 2 Consiglio per la Ricerca in Agricoltura e l'Analisi dell'Economia Agraria (CREA)—Research Centre for \\ Agricolture and Environment, Via della Navicella 2-4, I-00184 Rome, Italy; francesco.chianucci@crea.gov.it \\ 3 Department of Economic and Regional Development, Institute of Urban Environment and Human \\ Resources, Panteion University of Athens, 136 Syngrou Avenue, GR-17671 Athens, Greece; \\ mavrakisan@yahoo.gr \\ 4 School of Public Health and Tropical Medicine, Tulane University, 6823 St. Charles Avenue, New Orleans, \\ LA 70118, USA; nmorrow@tulane.edu \\ 5 Department DEIM, University of Tuscia, Via del Paradiso 47, I-01100 Viterbo, Italy; fabrizio.rossi@unitus.it \\ * Correspondence: giorgio.pontuale@crea.gov.it; Tel.: +39-06-6157-102
}

Received: 8 August 2018; Accepted: 24 October 2018; Published: 27 October 2018

check for updates

\begin{abstract}
Socioeconomic conditions and land management choices combine to affect changes in long-term wildfire regimes in Mediterranean-type ecosystems. Identification of specific drivers and dynamics at the local level is needed to inform land resource planning and to enhance wildfire management efficiency. Therefore, investigating feedback relationships between wildfire and socioeconomic conditions at local and regional scales can reveal consistency in spatial and temporal patterns influencing wildfire frequency, intensity, and severity. This study assessed long-term wildfire characteristics in Greece-one of the most fire-prone countries in Europe-over two consecutive time periods characterized by economic expansion (2000-2007) and recession (2008-2015). An integrated, multivariate statistical approach was implemented to assess the latent relationship between socioeconomic forces and localized wildfire regime indicators. Changes in the number of fires at the wildland-urban interface and duration of wildfires were consistent with expectations. Observed changes in the size of fires showed mixed results. Empirical findings of this study indicate analysis of wildfire regimes that takes into account both the socioeconomic and environmental factors in the overall territorial context of Mediterranean-type ecosystems, at both regional and local scale, may prove informative for the design of wildfire prevention measures in Greece.
\end{abstract}

Keywords: fires; urban sprawl; economic crisis; multivariate analysis; Mediterranean region

\section{Introduction}

Wildfires are a complex ecological problem in Mediterranean-type ecosystems that influence, but at the same time are strongly influenced by, the level and spatial distribution of economic activities and human settlements [1-4]. Wildfires have been shown to negatively impact land quality, biodiversity, ecosystem services, and local communities [5,6], with distinctive effects at local and regional scales [7-9]. Earlier studies carried out in the Mediterranean region have also identified feedback relationships between wildfires and socioeconomic dynamics. For instance, similar wildfire regimes were observed in Northern Morocco and Valencia, Spain before the 1970s [10], where moderate land abandonment and slight decreases in rural populations led to stable low-level accumulation of fuel in woodlands. 
More recent studies found that wildfire risk is associated with increased population density and the expansion of peri-urban areas [11-16]. Similarities in climate, soil, and vegetation suggest that wildfire regimes may also share similar underlying socioeconomic drivers in the Mediterranean region [17-21]. Historically, prescribed fires have been directly used by humans as a land management tool to adapt natural environments for economically-productive use, including agriculture and urban settlements [22-24]. Wildfires, on the other hand, are more often indirectly driven by land-use dynamics, socioeconomic conditions, and policy decisions not specifically related to fire prevention or response [25-28]. For instance, public budget cuts in response to the 2007 recession contributed significantly to underperformance in implementation of effective wildfire prevention policies and more sustainable forest management in southern Europe [29,30].

Wildfire regime designations are commonly created for a given region based on indicators available in geographical and statistical datasets, such as the number of wildfires and average burn area [31,32]. Maps of wildfire risk are an important component of land management plans, including forested areas. Appropriate forest management planning and wildfire prevention require comprehensive understanding of both land-use preferences and wildfire risk, including fire intensity, severity, and spatial distribution at a suitable scale [33,34]. Mediterranean-type ecosystems support a broad range of land-use types that often differ significantly at the local level. Local-scale wildfire regimes may therefore be shaped considerably by these location-specific socioeconomic conditions. Population density, population growth, building activity, land tenure, agricultural practices, and grazing pressure are found to correlate with the number of wildfires in peri-urban areas [35,36]. By contrast, wildfire size is determined largely by the additional fuel in rural areas with high land abandonment rates and low population density [37]. At the same time, local landscape structures (e.g., topography and vegetation features) and meteorological events such as aridity, prolonged droughts, and extreme winds affect wildfire frequency [38]. Appropriate data selection and spatial resolution of digital cartography are therefore essential to the quantitative assessment of wildfire risk in the Mediterranean region [1]. Evaluating risk in this region benefits from inclusion of socioeconomic variables in addition to available environmental data at the appropriate scale and over a sufficient period of time [39].

Based on these premises, this study investigates the association of the socioeconomic context to local wildfire regimes, using diachronic data collected at a regional level in Greece between 2000 and 2015. To test the hypothesis that economic activity and associated changes in the socioeconomic context over time causes changes in the number or severity of wildfires, we compared data collected from 2000 to 2007, which is characterized as a period of economic expansion, to data collected during and in the aftermath of a major economic recession from 2008 to 2015. Fine level geographic data are also used to test observations for expected differences in wildfire frequency and intensity. To do this, a large set of variables related to wildfire phenology (e.g., timing of fire events), severity (e.g., average burn area), and land cover are investigated along a geographical gradient typical of Southern European Mediterranean-type ecosystems.

\section{Methods}

\subsection{Study Area}

Greece, located in the Mediterranean basin, is the focus area of this study (Figure 1). At the southern tip of the Balkan Peninsula, Greece is characterized by a rugged topography and hundreds of islands spread across the Aegean Sea. The land area of $130,875 \mathrm{~km}^{2}$ includes a large variability in landscapes, climate, soils, and vegetation. The climate is typically Mediterranean over most of the country, with hot dry summers and mild winters. Little or no rain falls during the summer, with the dry season starting in April in many areas of the country. Southern Greece receives an average of $400 \mathrm{~mm}$ of rainfall annually. Maximum daily temperatures may exceed $40{ }^{\circ} \mathrm{C}$ for several days. Forest vegetation in Greece features a large variety of tree species reflecting weather variability, undulating topography, and moderate to poor soil quality [40]. Many tree and shrub species found in Greek 
forests, including several conifer species, are moderately to highly flammable, with a strong dependent relation between moisture content and flammability [34]. Additionally, the lower elevations and higher temperatures in southern and central Greece contribute to increased fire danger that is further exacerbated by interannual variability and the likely effects of climate change. Declining socioeconomic dynamics in rural areas of Greece have resulted in land abandonment and reforestation of former agricultural land, leading to fuel accumulation when forest management is absent, poorly informed, or ineffective [35,40-44]. The subnational administrative divisions in Greece were redrawn after the midpoint of our study period, in 2011. For consistency, the unit of analysis for this study are the fifty-one prefectures following the boundaries established in 1997.

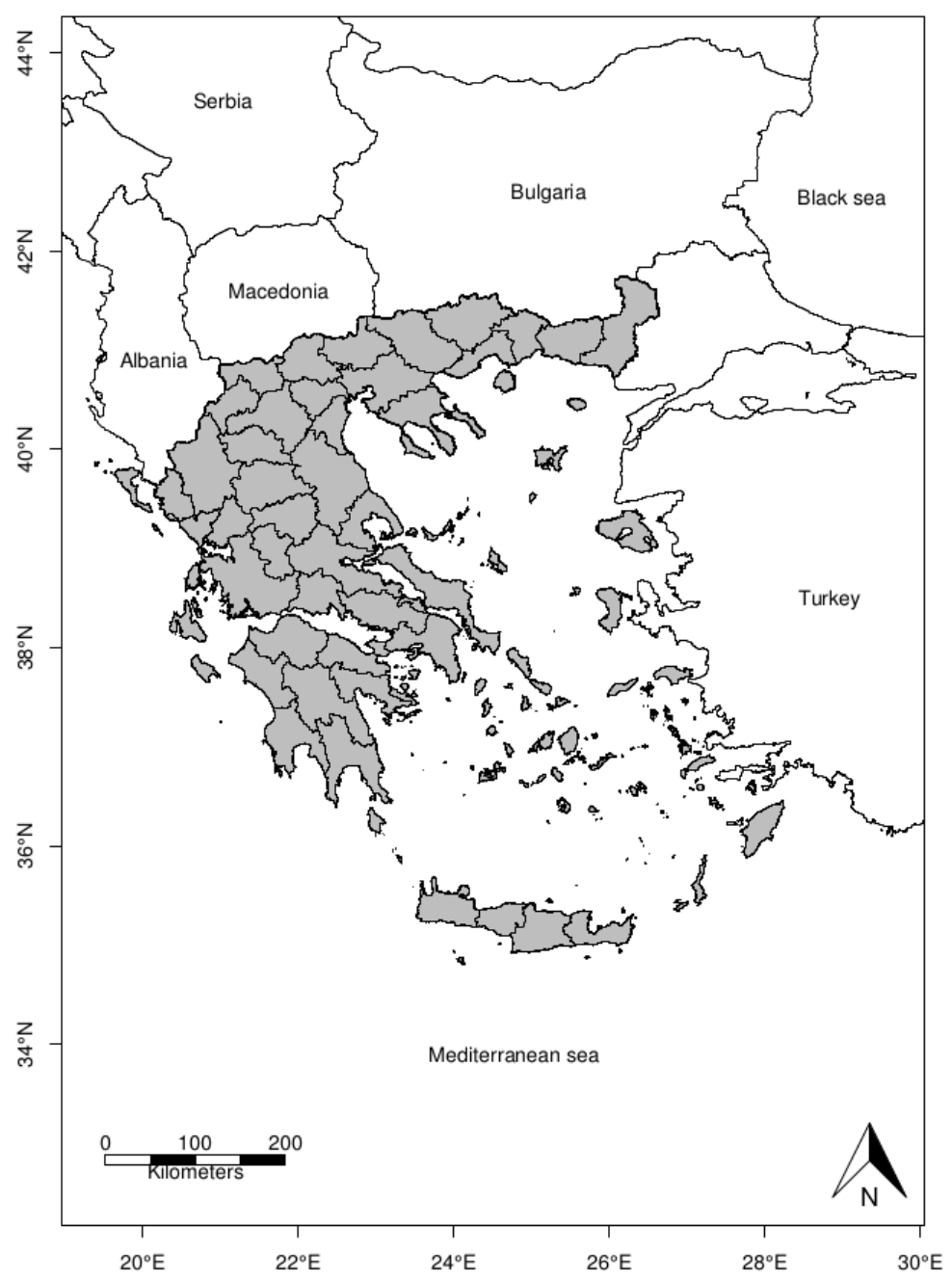

Figure 1. Study area and spatial distribution of prefectures in Greece.

The prefectures in the study area are grouped into four typologies, reflecting selected territorial and topographic characteristics that are consistent with socioeconomic profiles from earlier studies $[34,36,40,42,43]$ (see Table 1). The wildfire regimes in the first and second time periods are then analyzed separately for each prefecture. Typology groups are then used in reporting and interpretation of the results. 
Table 1. Basic typologies of Greek prefectures.

\begin{tabular}{cll}
\hline \multicolumn{1}{c}{ Typology } & \multicolumn{1}{c}{ Prefectures } \\
\hline 1 & $\begin{array}{l}\text { Economically marginal rural areas } \\
\text { with moderate-poor accessibility }\end{array}$ & $\begin{array}{l}\text { Artas, Dramas, Etoloakarnanias, Evrytanias, Florinas, } \\
\text { Fokidas, Fthiotidas, Grevenon, Ilias, Imathias, } \\
\text { Ioanninon, Karditsas, Kastorias, Kilkis, Kozanis, } \\
\text { Pellas, Pierias, Rodopis, Serron, Thesprotias, Xanthis }\end{array}$ \\
\hline \multirow{2}{*}{$\begin{array}{l}\text { Agricultural regions with } \\
\text { intermediate population density and } \\
\text { moderate accessibility from the capital }\end{array}$} & $\begin{array}{l}\text { Achaias, Argolidas, Arkadias, Evrou, Evvias, } \\
\text { Kavalas, Korinthou, Lakonias, Lasithiou, Lefkadas, } \\
\text { Messinias, Prevezas, Trikalon, Trikalon, Viotias }\end{array}$ \\
\hline \multirow{2}{*}{$\begin{array}{l}\text { Areas with uneven urbanization } \\
4\end{array}$} & $\begin{array}{l}\text { Coastal, island or peninsular areas } \\
\text { specialized in tourism sector }\end{array}$ & $\begin{array}{l}\text { Athens, Iraklio, Larisa, Thessaloniki } \\
\text { Chalkidikis, Chanion, Chiou, Dodekanison, } \\
\text { Kefallonias, Kykladon, Lesvou, Magnisias, } \\
\text { Rethymnou, Samou, Zakynthou }\end{array}$ \\
\hline
\end{tabular}

\subsection{Data from Wildfires}

This study includes data from more than 130,000 fire events that were collected by the Hellenic Fire Brigade between 2000 and 2015. For each fire event, the data record contains the date, hour, and place of ignition. Estimations of the burn area are broken down by basic land cover classes, following a classification system similar to Corine Land Cover nomenclature. Pielou's J Evenness Index (J), as a proxy for landscape heterogeneity, was included in the data set [36]. Values of the index are lower when fewer land cover types are effected and higher when there are many types of land cover in the burn area. Variable descriptions for the Hellenic Fire Brigade data are presented in Table 2. Variables for analysis were selected from basic and well-known wildfire indicators described in the literature [34,36].

Table 2. List of wildfire variables for analysis in this study.

\begin{tabular}{ll}
\hline \multicolumn{1}{c}{ Acronym } & \multicolumn{1}{c}{ Description } \\
\hline JUL & Ignition date ranging between 0 and 1 (Julian calendar day rank/365 days) \\
HOU & Ignition hour ranging between 0 and 1 \\
EXT & Wildfire's extinguishing time per space unit (min, logarithm) \\
AREA & Average forest burnt area (ha, logarithm) \\
CLASS & Number of land-use classes affected by wildfires to burnt area \\
FORESTS & Forest burnt area in total burnt area, forest and non-forest (\%) \\
WOODED & Wooded burnt area (shrubland, maquis, garigue) in total burnt area (\%) \\
PARKS & Urban parks and garden burnt area in total burnt area (\%) \\
PASTURES & Pastures and sparsely vegetated burnt areas in total burnt area (\%) \\
WETLANDS & Riparian vegetation and residual surrounding burnt land in total burnt area (\%) \\
AGRICULTURE & Agricultural burnt area in total burnt area (\%) \\
GARDEN CROP & Sparse cultivation burnt area in total burnt area (\%) \\
J & Pielou J Eveness Index in the statistical distribution of land-use affected by wildfires \\
\hline
\end{tabular}

\subsection{Statistical Analysis}

An analytical strategy of data analysis mixing nonparametric inference, linear discriminant analysis (LDA), and hierarchical clustering aims to assess the impact of the 2007 economic recession on wildfire regimes in Greek prefectures $[41,45,46]$. A comparative analysis of selected wildfire characteristics (see Table 2) was employed to confirm that significant differences exist between time intervals at $p<0.05$ level. Bonferroni's correction for multiple comparisons was applied as necessary. The LDA then identified and ranked the importance of variables in distinguishing wildfire patterns between the two time intervals in each Greek prefecture. LDA was performed using a forward stepwise approach, with a strict threshold based on a Fisher statistic (i.e., F-to-remove and F-to-enter) set at 
10 and 5, respectively. This approach was adopted to remove multicollinear variables from analysis and reduce the overall redundancy of the data matrix.

Finally, hierarchical clustering was run on the same data matrix with the aim to group data on the basis of the spatial distribution of wildfire indicators at the prefecture level [47]. A two-way hierarchical clustering under Euclidean distances and Ward agglomeration rule was run to group similar variables and spatial units according to the available information from the abovementioned dataset. The statistical approach adopted in this study provides a comprehensive analysis of wildfire characteristics over time and space, giving value to the information collected in light of the hypothesis that economic conditions, specifically economic recession, may influence local-scale wildfire characteristics.

\section{Results and Discussion}

\subsection{Basic Statistics}

Median values for each indicator by prefecture and time period are included in the Supplementary Materials as Table S1. Median values were preferred to average values, since the statistical distribution of most indicators showed some deviations from normality. The frequency distribution of the burn area (A) is shown in Figure 2. The linear decrease in log-log scale and logarithmic bins' size indicate a power law form $\left(\mathrm{f}(\mathrm{A})=\mathrm{kA}^{-\lambda}\right.$ ), with $\lambda \cong 1.87$. This Pareto-like distribution is typical of systems with a heterogeneous scale and intrinsic complexity. The Pareto principle describes phenomena where relatively few events or agents are responsible for most of the impact, such as: (i) To describe nonlinear processes, such as the amplitude of earthquakes (Gutemberg-Richter law) [48] and the SOC (Self-Organized Criticality) phenomena [49] in physics; (ii) to assess the frequency of the use of words in a written text [50]; and (iii) to evaluate complex socioeconomic phenomena in financial studies [51].

A nonparametric Mann-Whitney $U$ test was run to test the null-hypothesis that the two samples of variables recorded during 2000-2007 and 2008-2015 were extracted from populations having the same distribution. Our results reject this null-hypothesis at a $p<0.05$ test level, confirming significant differences for specific variables between the two study intervals. For example, the decrease of the wildfire burn area in the second (recession) period was statistically significant.

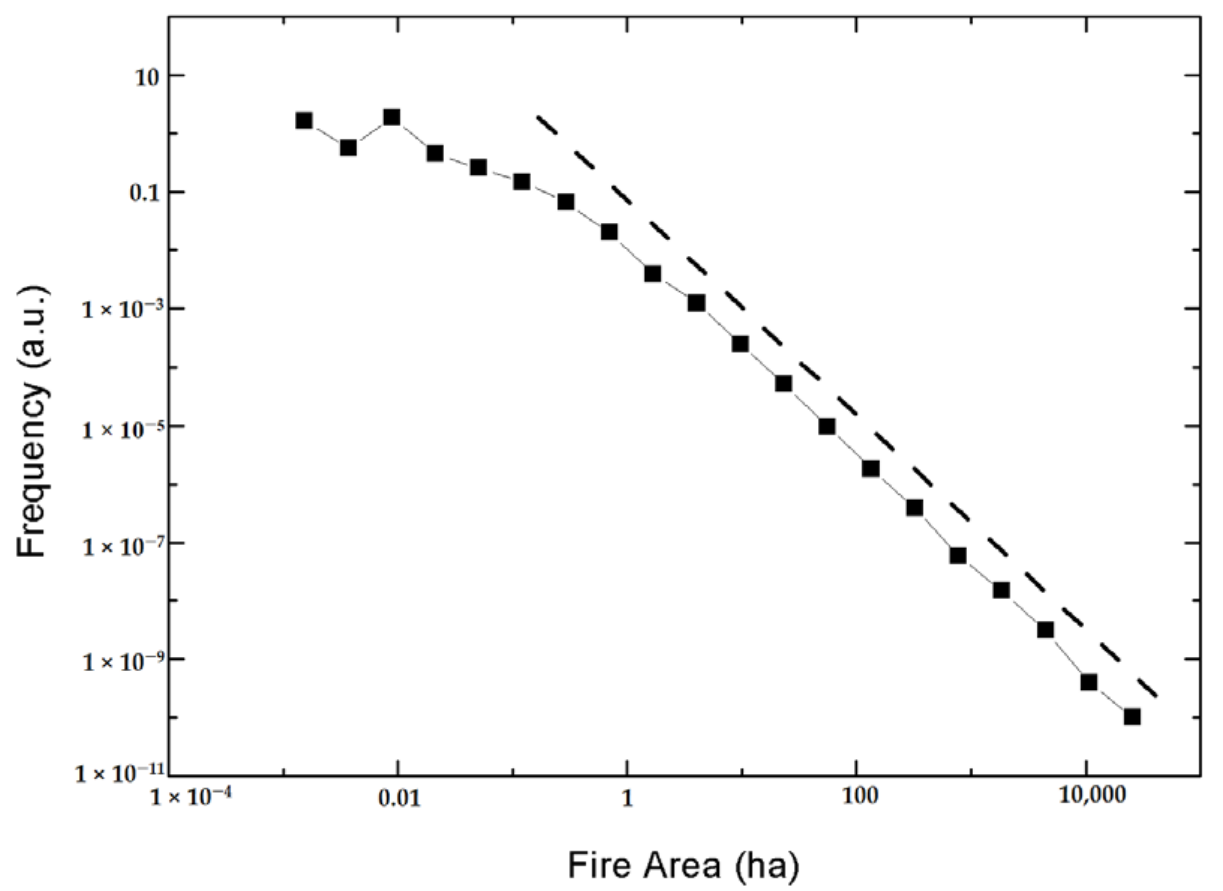

Figure 2. Frequency distribution of wildfire area; the dashed line has a slope $\lambda \cong-1.87$ in $\log -\log$ scale. 


\subsection{Linear Discriminant Analysis (LDA)}

We performed a linear discriminant analysis on the thirteen indicators listed in Table 1 for each prefecture to identify the most relevant variables for explaining differences in wildfire regimes between the two subperiods. LDA provides a $p$-value estimating the ability of each variable to discriminate between the 2000-2007 period of expansion and the 2008-2015 period of recession. Therefore, a higher number of significant variables identified by LDA would reflect a wildfire regime changing more rapidly over time. Empirical results of this study suggest that wildfire regime indicators across Greek prefectures are sensitive to changes in economic conditions between the period of expansion and recession (Figure 3).
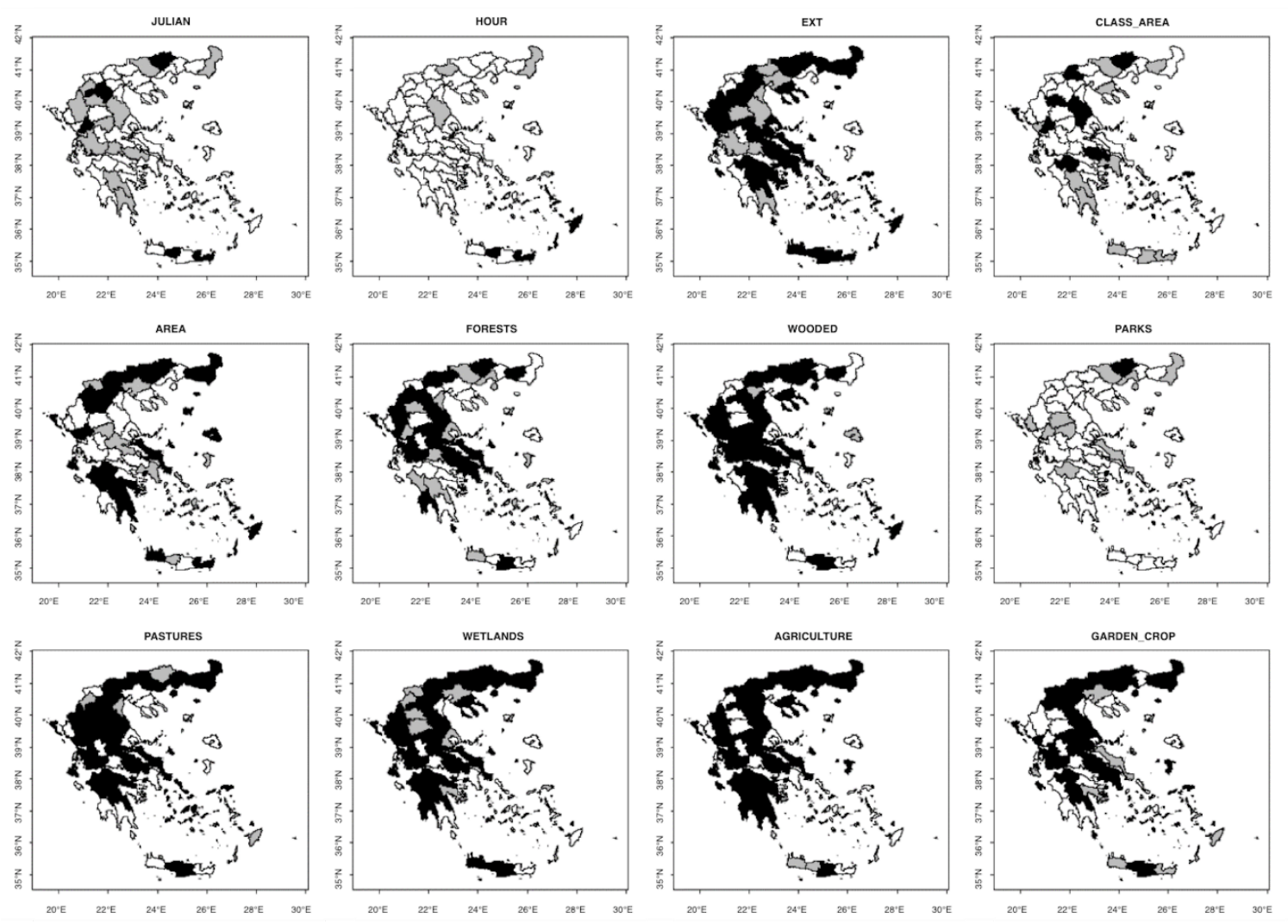

Figure 3. Variables discriminating wildfire regimes in Greek prefectures based on linear discriminant analysis (LDA) (white, $p \geq 0.05$ (nonsignificant); grey, $0.05 \leq p \geq 0.001$ (moderately significant); black, $p \leq 0.001$ (highly significant)).

LDA models were significant $(p<0.05)$ for all Greek prefectures. Depending on the prefecture, between one and ten of the thirteen total wildfire variables were significantly different in the economic recession period that followed the economic expansion. The largest number of significant variables were observed in dry and inland rural areas from Arkadias to Viotias. By comparison, accessible tourism-specialized coastal areas, from Chalkidikis to Evrytania, only between one and four variables were identified with a significant change between time periods. A larger change in the local fire regime is implied by a higher number of variables demonstrating a significant change, and this is observed in a convincing number of prefectures. This empirical evidence confirms the working hypothesis of this study that changing social and economic conditions potentially make wildfire regimes more volatile and unpredictable. This is particularly true for inland rural areas characterized by moderate climate aridity and relatively high forest cover, such as Arkadias, Arta, and Drama, which became vulnerable to large fires during the economic downturn. Budgetary restrictions to forest management plans, coupled with fuel accumulation associated with land abandonment, may explain the observed 
relationship of fire size to the economic conditions in these areas. Conversely, a few variables had significant differences in coastal, flat prefectures with medium-high population density and improved accessibility (Figure 4).

These results indicate a more stable wildfire regime in coastal ecosystems that were less sensitive to or less impacted by economic downturns in terms of fire vulnerability. The EXT indicator was the most relevant discriminating variable across the whole country, with significant differences $(p<0.05)$ between the time periods in more than 75 percent of Greek prefectures (Figure 4). In more than 50 percent of Greek prefectures, land cover type (Wetlands, Garden crop, Agriculture, Wooded, Pastures, and Forests) showed significant differences between time periods. The burn area was a significant variable in nearly 60 percent of Greek prefectures. Conversely, the 'Parks' land cover type variable was significant only in a few cases $(18 \%)$. The Julian day and the hour of the day were rarely significant. Taken together, urbanized prefectures such as Athens, Thessaloniki, and Iraklion and tourism districts, including the Cyclades islands, exhibited a wildfire regime different than those observed in internal and mountainous prefectures (such as Thesprotia and Thrace) or in rural and dry regions with relict forests (Southern Peloponnese, Lakonia, Messinia, Acaia, Argolida, and Korintias).

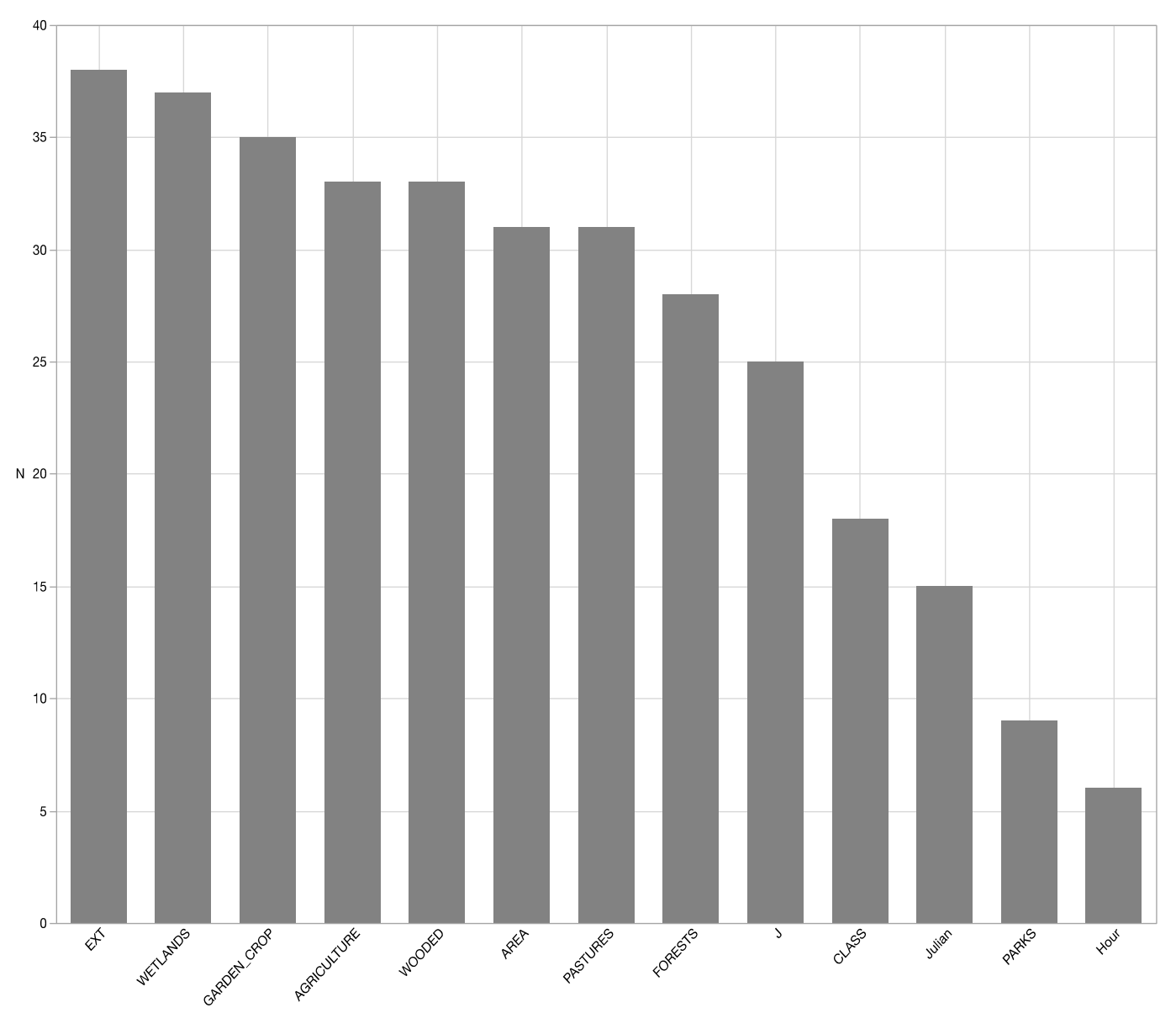

Figure 4. Number of prefectures with significant $(p<0.05)$ variables discriminating among wildfires' regimes (during economic expansion and recession) based on the LDA, by variable (acronyms in Table 2).

\subsection{Hierarchical Clustering}

Figure 5 shows the results of a two-way hierarchical clustering (Euclidean distances, Ward agglomeration rule) run with the aim to group prefectures based on similarity in the 13 wildfire variables. The hierarchical clustering algorithm classified the prefectures into two main clusters and further into six subclusters. At the highest level, clustering discriminated areas with high anthropic pressure from rural areas, coastal districts, and islands. Urban and suburban prefectures, such as 
Athens, Magnisias, Kykladon, and Thessaloniki, showed high human pressure, heterogeneous land cover, and distinct wildfire regimes. The other prefectures clustered based on more homogenous land cover types. The dynamics across these classifications reflect possible influence by a changing background of socioeconomic conditions (Figure 5).

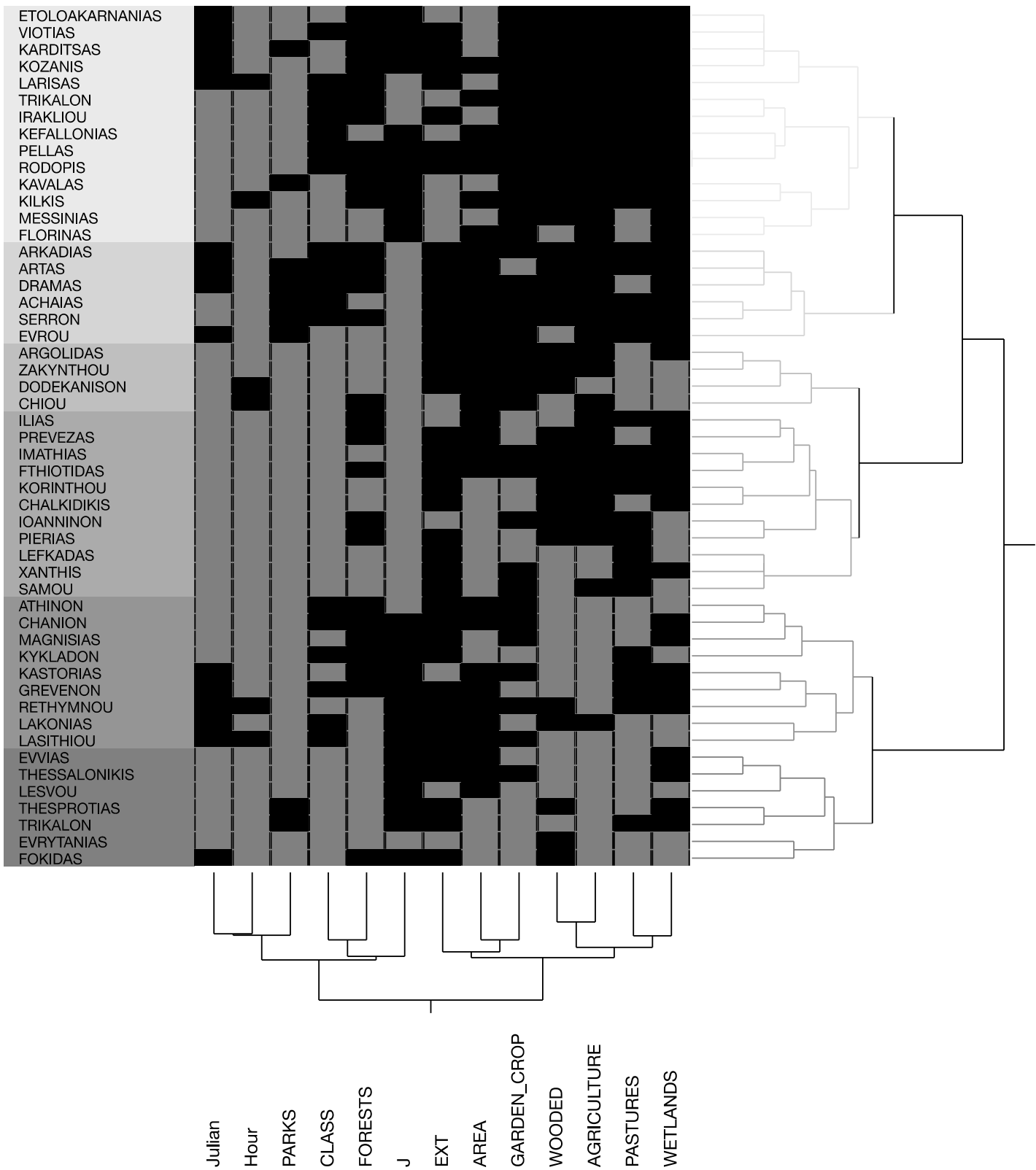

Figure 5. Hierarchical clustering of prefectures and wildfire variables.

\subsection{Wildfire Regimes before and during the 2007 Recession}

The specific results of hierarchical clustering are presented in Table 3. Variables JUL, EXT, AREA, and CLASS are the most relevant in distinguishing between prefectures based on differences between the time periods according to $p$-values derived from the LDA. Full details are available in Supplementary Materials, Table S2. Table 3 therefore summarizes the direction of change for these variables, taking into consideration the basic typologies presented in Table 1. Increased extinguishing time is highly consistent with the expectation of fewer resources available for forest and wildfire management during the recession. Indicated by changes in the J Evenness Index, decreases in heterogeneity for the urban 
areas are similarly confirmatory of the hypothesis that the number of fires at the wildland-urban interface is related to the level of economic activity. The expectation that wildfires would become larger due to fuel accumulation in a recession had mixed results, perhaps due to the length of time periods included in the analysis.

Table 3. Selected characteristics of wildfire regimes based on economic typologies of Greek prefectures (Table 1).

\begin{tabular}{|c|c|c|c|c|c|}
\hline & Economic Typology & Wildfire Phenology & $\begin{array}{l}\text { Extinguishing } \\
\text { Time }\end{array}$ & Wildfire Size & $\begin{array}{c}\text { Landscape } \\
\text { Heterogeneity }\end{array}$ \\
\hline 1 & $\begin{array}{l}\text { Economically marginal } \\
\text { rural areas with poor } \\
\text { accessibility }\end{array}$ & $\begin{array}{l}\text { Except for Dramas, it } \\
\text { decreases or remains } \\
\text { nearly constant }\end{array}$ & $\begin{array}{l}\text { Except for Artas } \\
\text { and Thesprotias, } \\
\text { it increases }\end{array}$ & $\begin{array}{l}\text { Except for } \\
\text { Karditsas, it } \\
\text { decreases or } \\
\text { remains constant }\end{array}$ & $\begin{array}{l}\text { It increases or } \\
\text { remains constant }\end{array}$ \\
\hline 2 & $\begin{array}{l}\text { Agricultural regions } \\
\text { with intermediate } \\
\text { population density and } \\
\text { moderate accessibility } \\
\text { from the capital city }\end{array}$ & $\begin{array}{l}\text { Except for Lakonias, } \\
\text { it decreases }\end{array}$ & $\begin{array}{l}\text { Except for Evrou, } \\
\text { it increases }\end{array}$ & $\begin{array}{l}\text { Except for } \\
\text { Karditsas, it } \\
\text { decreases or } \\
\text { remains constant }\end{array}$ & $\begin{array}{l}\text { Except for Achaias, } \\
\text { it increases or } \\
\text { remains nearly } \\
\text { constant }\end{array}$ \\
\hline 3 & $\begin{array}{l}\text { Urban areas with heavy } \\
\text { consumption of land }\end{array}$ & $\begin{array}{l}\text { Except for Athens } \\
\text { (where it strongly } \\
\text { decreases), it is not } \\
\text { significant }\end{array}$ & It increases & It remains constant & $\begin{array}{l}\text { It decreases or } \\
\text { remains constant }\end{array}$ \\
\hline 4 & $\begin{array}{l}\text { Coastal, island or } \\
\text { peninsular areas with } \\
\text { important tourism }\end{array}$ & $\begin{array}{l}\text { Except for Kykladon } \\
\text { (where it strongly } \\
\text { decreases), it is not } \\
\text { significant }\end{array}$ & It increases & $\begin{array}{l}\text { Except for Samou, } \\
\text { it decreases or } \\
\text { remains constant }\end{array}$ & $\begin{array}{l}\text { Except for } \\
\text { Kefallonias, it } \\
\text { decreases or } \\
\text { remains constant }\end{array}$ \\
\hline
\end{tabular}

\section{Conclusions}

Economic recession in Mediterranean countries has led to land abandonment in isolated rural areas, while at the same time promoting agricultural intensification of the most fertile areas [36,52-54]. Assuming that transformations in the forest environment may lead to significant changes in the supply of ecosystem services [55], an understanding of wildfire phenology as an essential component of forest management and planning is vital to desirable social, economic, and environmental outcomes [56-58]. More efficient fire management can be fostered by pinpointing the characteristics of the wildfire dynamics and processes with analytic tools and methods [59-66]. In this regard, a multivariate analysis of socioeconomic factors may shed light on local-scale wildfire regimes [67]. Our results identify specific wildfire regimes for a period of economic expansion and a period of recession that may have both a direct and an indirect impact on land sensitivity to wildfires. Wildfire regimes for inland districts showed the greatest sensitivity to economic changes, reflected in significant differences for the majority of variables used in the analysis. Conversely, coastal areas had relatively more stable regimes, with fewer variables sensitive to expansion or recession.

These findings provide supporting evidence for the role of land abandonment and human pressure on wildfire regimes along a population density gradient in Greece. The former process indirectly stimulates fuel accumulation, determining larger fires in rural, economically-disadvantaged regions. The latter process is more clearly associated with an increasing number of fires at the wildland-urban interface, as observed in coastal and flat areas around metropolitan regions or tourism districts. Understanding place-specific complexity in wildfire regimes under economic downturns provides relevant knowledge for fire prevention measures that can be adapted to rapidly changing conditions at both local and regional scale. In this regard, such an analysis will enable policy-makers and fire managers to design more consistent long-term strategies in sustainable forest management, taking into consideration the different time horizons for environmental and socioeconomic factors. Monitoring the impact of wildfires on landscape fragmentation and ecosystem deterioration may in turn support sustainable land planning strategies with an indirect, positive feedback on fire management. 
Supplementary Materials: The following are available online at http:/ /www.mdpi.com/2071-1050/10/11/3911/s1, Table S1: Wildfire regimes, Table S2: hierarchical clustering.

Author Contributions: Conceptualization, F.C. and C.F.; Methodology, M.M. and G.P.; Software: E.P.; Validation: L.S. and F.R.; Formal Analysis, M.M. and C.F.; Investigation, F.C.; Resources, F.R.; Data Curation, C.F.; Writing-Original Draft Preparation, L.S. and F.C.; Writing-Review \& Editing, G.P. and N.M.; Visualization, E.P. and N.M.; Funding Acquisition, F.R.

Funding: This research received no external funding.

Acknowledgments: We would acknowledge the technical support provided by SAUS initiative 'Sostenibilità ambientale e uso del suolo' carried out in cooperation with Latium region and Alpha Consult s.r.l.

Conflicts of Interest: The authors declare no conflict of interest.

\section{References}

1. Corona, P.; Ascoli, D.; Barbati, A.; Bovio, G.; Colangelo, G.; Elia, M.; Garfi, V.; Iovino, F.; Lafortezza, R.; Leone, V.; et al. Integrated forest management to prevent wildfires under Mediterranean environments. Ann. Silvic. Res. 2015, 39, 1-22. [CrossRef]

2. Keeley, J.E. Fire intensity, fire severity and burn severity: A brief review and suggested usage. Int. J. Wildland Fire 2009, 18, 116-126. [CrossRef]

3. Keeley, J.E. Fire in Mediterranean Ecosystems: Ecology, Evolution and Management; Cambridge University Press: Cambridge, UK; New York, NY, USA, 2012; ISBN 978-1-139-16080-3.

4. Bond, W.J.; van Wilgen, B.W. Fire and Plants; Population and Community Biology Series; Springer: Amsterdam, The Netherlands, 1996; ISBN 978-0-412-47540-5.

5. Chiriacò, M.; Perugini, A.L.; Cimini, A.D.; D’Amato, B.E.; Valentini, R.; Bovio, G.; Corona, P.; Barbati, A. Comparison of approaches for reporting forest fire-related biomass loss and greenhouse gas emissions in southern Europe. Int. J. Wildland Fire 2013, 22, 730-738. [CrossRef]

6. Jacobson, M.Z. Effects of biomass burning on climate, accounting for heat and moisture fluxes, black and brown carbon, and cloud absorption effects: Effects of biomass burning on climate. J. Geophys. Res. Atmos. 2014, 119, 8980-9002. [CrossRef]

7. Pyne, S.J.; Andrews, P.L.; Laven, R.D. Introduction to Wildland Fire; Wiley: Hoboken, NJ, USA, 1996.

8. Kasischke, E.S.; Christensen, N.L.; Stocks, B.J. Fire, Global Warming, and the Carbon Balance of Boreal Forests. Ecol. Appl. 1995, 5, 437-451. [CrossRef]

9. Levine, J.S. Biomass Burning and Global Change: Remote Sensing, Modeling and Inventory Development, and Biomass Burning in Africa; MIT Press: Cambridge, MA, USA, 1996; ISBN 978-0-262-12201-6.

10. Chergui, B.; Fahd, S.; Santos, X.; Pausas, J.G. Socioeconomic Factors Drive Fire-Regime Variability in the Mediterranean Basin. Ecosystems 2018, 21, 619-628. [CrossRef]

11. Tedim, F.; Xanthopoulos, G.; Leone, V. Chapter 5-Forest Fires in Europe: Facts and Challenges. In Wildfire Hazards, Risks and Disasters; Shroder, J.F., Paton, D., Eds.; Elsevier: Oxford, UK, 2015; pp. 77-99. ISBN 978-0-12-410434-1.

12. Salvati, L.; Zitti, M. Land degradation in the Mediterranean Basin: Linking bio-physical and economic factors into an ecological perspective. Ital. J. Agron. 2005, 6, 67-77.

13. Munafò, M.; Salvati, L.; Zitti, M. Estimating soil sealing rate at national level-Italy as a case study. Ecol. Indic. 2013, 26, 137-140. [CrossRef]

14. Carlucci, M.; Grigoriadis, E.; Rontos, K.; Salvati, L. Revisiting a Hegemonic Concept: Long-term 'Mediterranean Urbanization' in Between City Re-polarization and Metropolitan Decline. Appl. Spat. Anal. Policy 2016, 10. [CrossRef]

15. Cuadrado-Ciuraneta, S.; Guimerà, A.; Salvati, L. Not only tourism: Unravelling suburbanization, second-home expansion and "rural" sprawl in Catalonia, Spain. Urban Geogr. 2016, 38, 1-24. [CrossRef]

16. Jappiot, M.; Gonzalez-Olabarria, J.R.; Lampin-Maillet, C.; Borgniet, L. Assessing Wildfire Risk in Time and Space. In Living with Wildfires: What Science Can Tell Us. A Contribution to the Science-Policy Dialogue; European Forest Institute: Joensuu, Finland, 2009; pp. 41-47.

17. Sebastián-López, A.; Salvador-Civil, R.; Gonzalo-Jiménez, J.; SanMiguel-Ayanz, J. Integration of socio-economic and environmental variables for modelling long-term fire danger in Southern Europe. Eur. J. For. Res. 2008, 127, 149-163. [CrossRef] 
18. Bajocco, S.; Salvati, L.; Ricotta, C. Land degradation versus fire: A spiral process? Prog. Phys. Geogr. Earth Environ. 2011, 35, 3-18. [CrossRef]

19. Salvati, L.; Petitta, M.; Ceccarelli, T.; Perini, L.; Battista, F.D.; Scarascia, M.E.V. Italy's renewable water resources as estimated on the basis of the monthly water balance. Irrig. Drain. 2008, 57, 507-515. [CrossRef]

20. Salvati, L.; Carlucci, M. The economic and environmental performances of rural districts in Italy: Are competitiveness and sustainability compatible targets? Ecol. Econ. 2011, 70, 2446-2453. [CrossRef]

21. Salvati, L.; Zitti, M. Monitoring vegetation and land use quality along the rural-urban gradient in a Mediterranean region. Appl. Geogr. 2012, 32, 896-903. [CrossRef]

22. Cissel, J.H.; Swanson, F.J.; Weisberg, P.J. Landscape Management Using Historical Fire Regimes: Blue River, Oregon. Ecol. Appl. 1999, 9, 1217. [CrossRef]

23. Cochrane, M.A. Fire science for rainforests. Nature 2003, 421, 913-919. [CrossRef] [PubMed]

24. Rego, F.; Silva, J. Wildfires and landscape dynamics in Portugal: A regional assessment and global implications. For. Landsc. Glob. Chang. 2014, 51-73. [CrossRef]

25. Henderson, M.; Kalabokidis, K.; Marmaras, E.; Konstantinidis, P.; Marangudakis, M. Fire and Society: A Comparative Analysis of Wildfire in Greece and the United States. Hum. Ecol. Rev. 2005, 12, 169-182.

26. Salvati, L.; Perini, L.; Sabbi, A.; Bajocco, S. Climate Aridity and Land Use Changes: A Regional-Scale Analysis. Geogr. Res. 2012, 50, 193-203. [CrossRef]

27. Colantoni, A.; Mavrakis, A.; Sorgi, T.; Salvati, L. Towards a 'polycentric' landscape? Reconnecting fragments into an integrated network of coastal forests in Rome. Rendiconti Lincei 2015, 26, 615-624. [CrossRef]

28. Pili, S.; Grigoriadis, E.; Carlucci, M.; Clemente, M.; Salvati, L. Towards sustainable growth? A multi-criteria assessment of (changing) urban forms. Ecol. Indic. 2017, 76, 71-80. [CrossRef]

29. Salvati, L.; Serra, P. Estimating Rapidity of Change in Complex Urban Systems: A Multidimensional, Local-Scale Approach. Geogr. Anal. 2016, 48, 132-156. [CrossRef]

30. Duvernoy, I.; Zambon, I.; Sateriano, A.; Salvati, L. Pictures from the other side of the fringe: Urban growth and peri-urban agriculture in a post-industrial city (Toulouse, France). J. Rural Stud. 2018, 57, 25-35. [CrossRef]

31. You, W.; Lin, L.; Wu, L.; Ji, Z.; Yu, J.; Zhu, J.; Fan, Y.; He, D. Geographical information system-based forest fire risk assessment integrating national forest inventory data and analysis of its spatiotemporal variability. Ecol. Indic. 2017, 77, 176-184. [CrossRef]

32. Modugno, S.; Balzter, H.; Cole, B.; Borrelli, P. Mapping regional patterns of large forest fires in Wildland-Urban Interface areas in Europe. J. Environ. Manag. 2016, 172, 112-126. [CrossRef] [PubMed]

33. Bar Massada, A.; Radeloff, V.C.; Stewart, S.I.; Hawbaker, T.J. Wildfire risk in the wildland-urban interface: A simulation study in northwestern Wisconsin. For. Ecol. Manag. 2009, 258, 1990-1999. [CrossRef]

34. Salvati, L.; Ferrara, A. Do Land Cover Changes Shape Sensitivity to Forest Fires in peri-urban Areas? Urban For. Urban Green. 2014, 13, 571-575. [CrossRef]

35. Moreira, F.; Viedma, O.; Arianoutsou, M.; Curt, T.; Koutsias, N.; Rigolot, E.; Barbati, A.; Corona, P.; Vaz, P.; Xanthopoulos, G.; et al. Landscape-wildfire interactions in Southern Europe: Implications for landscape management. J. Environ. Manag. 2011, 92, 2389-2402. [CrossRef] [PubMed]

36. Salvati, L. Profiling forest fires along the urban gradient: A Mediterranean case study. Urban Ecosyst. 2014, 17, 1175-1189. [CrossRef]

37. Bajocco, S.; Rosati, L.; Ricotta, C. Knowing fire incidence through fuel phenology: A remotely sensed approach. Ecol. Model. 2010, 59-66. [CrossRef]

38. Fares, S.; Bajocco, S.; Salvati, L.; Camarretta, N.; Dupuy, J.; Xanthopoulos, G.; Guijarro, M.; Madrigal, J.; Hernando, C.; Corona, P. Characterizing potential wildland fire fuel in live vegetation in the Mediterranean region. Ann. For. Sci. 2017, 74. [CrossRef]

39. Salvati, L.; Zitti, M.; Ceccarelli, T. Integrating economic and environmental indicators in the assessment of desertification risk: A case study. Appl. Ecol. Environ. Res. 2007, 6. [CrossRef]

40. Koutsias, N.; Arianoutsou, M.; Kallimanis, A.S.; Mallinis, G.; Halley, J.M.; Dimopoulos, P. Where did the fires burn in Peloponnisos, Greece the summer of 2007? Evidence for a synergy of fuel and weather. Agric. For. Meteorol. 2012, 156, 41-53. [CrossRef]

41. Salvati, L.; Morelli, V.G.; Rontos, K.; Sabbi, A. Latent Exurban Development: City Expansion Along the Rural-To-Urban Gradient in Growing and Declining Regions of Southern Europe. Urban Geogr. 2013, 34, 376-394. [CrossRef] 
42. Karamesouti, M.; Detsis, V.; Kounalaki, A.; Vasiliou, P.; Salvati, L.; Kosmas, C. Land-use and land degradation processes affecting soil resources: Evidence from a traditional Mediterranean cropland (Greece). CATENA 2015, 132, 45-55. [CrossRef]

43. Kosmas, C.; Karamesouti, M.; Kounalaki, K.; Detsis, V.; Vassiliou, P.; Salvati, L. Land degradation and long-term changes in agro-pastoral systems: An empirical analysis of ecological resilience in Asteroussia-Crete (Greece). CATENA 2016, 147, 196-204. [CrossRef]

44. Xanthopoulos, G.; Caballero, D.; Galante, M.; Alexandrian, D.; Rigolot, E.; Marzano, R. Forest Fuels Management in Europe. In Proceedings of the Fuels Management-How to Measure Success, Portland, OR, USA, 28-30 March 2006; Andrews, P.L., Butler, B.W., Eds.; USDA Forest Service: Fort Collins, CO, USA, 2006; pp. 29-46.

45. Mika, S.; Ratsch, G.; Weston, J.; Scholkopf, B.; Mullers, K.R. Fisher discriminant analysis with kernels. In Proceedings of the 1999 IEEE Signal Processing Society Workshop (Cat. No.98TH8468) on Neural Networks for Signal Processing IX, Madison, WI, USA, 25 August 1999; pp. 41-48.

46. Ceccarelli, T.; Bajocco, S.; Luigi Perini, L.; Luca Salvati, L. Urbanisation and Land Take of High Quality Agricultural Soils-Exploring Long-term Land Use Changes and Land Capability in Northern Italy. Int. J. Environ. Res. 2014, 8, 181-192. [CrossRef]

47. Salvati, L. Monitoring high-quality soil consumption driven by urban pressure in a growing city (Rome, Italy). Cities 2013, 31, 349-356. [CrossRef]

48. Gutenberg, B.; Richter, C.F. Frequency of earthquakes in California. Bull. Seismol. Soc. Am. 1944, 34, $185-188$.

49. Petri, A.; Pontuale, G. Morphology and dynamics in SOC universality classes. J. Stat. Mech. Theory Exp. 2018, 2018, 063201. [CrossRef]

50. Pietronero, L.; Tosatti, E.; Tosatti, V.; Vespignani, A. Explaining the uneven distribution of numbers in nature: The laws of Benford and Zipf. Phys. A Stat. Mech. Appl. 2001, 293, 297-304. [CrossRef]

51. Gabaix, X. Power Laws in Economics and Finance. Annu. Rev. Econ. 2009, 1, 255-294. [CrossRef]

52. Serra, P.; Martín, A.; Tulla, A.; Salvati, L. Beyond urban-rural dichotomy: Exploring socioeconomic and land-use processes of change in Spain (1991-2011). Appl. Geogr. 2014, 55, 71-81. [CrossRef]

53. Salvati, L.; Ferrara, A. Validation of MEDALUS Fire Risk Index using Forest Fires Statistics through a multivariate approach. Ecol. Indic. 2015, 48, 365-369. [CrossRef]

54. Zitti, M.; Ferrara, C.; Perini, L.; Carlucci, M.; Salvati, L. Long-Term Urban Growth and Land Use Efficiency in Southern Europe: Implications for Sustainable Land Management. Sustainability 2015, 2015, 3359-3385. [CrossRef]

55. de Groot, R.S.; Alkemade, R.; Braat, L.; Hein, L.; Willemen, L. Challenges in integrating the concept of ecosystem services and values in landscape planning, management and decision making. Ecol. Complex. 2010, 7, 260-272. [CrossRef]

56. Barbati, A.; Corona, P.; Salvati, L.; Gasparella, L. Natural forest expansion into suburban countryside: Gained ground for a green infrastructure? Urban For. Urban Green. 2013, 12, 36-43. [CrossRef]

57. Bajocco, S.; Dragoz, E.; Gitas, I.; Smiraglia, D.; Salvati, L.; Ricotta, C. Mapping Forest Fuels through Vegetation Phenology: The Role of Coarse-Resolution Satellite Time-Series. PLoS ONE 2015, 10, e0119811. [CrossRef] [PubMed]

58. De Angelis, A.; Bajocco, S.; Ricotta, C. Phenological variability drives the distribution of wildfires in Sardinia. Landsc. Ecol. 2012, 27, 1535-1545. [CrossRef]

59. Cardille, J.; Ventura, S.; Turner, M. Environmental and Social Factors Influencing Wildfires in the Upper Midwest, United States. Ecol. Appl. 2001, 11, 111-127. [CrossRef]

60. Sturtevant, B.R.; Cleland, D.T. Human and biophysical factors influencing modern fire disturbance in northern Wisconsin. Int. J. Wildland Fire 2007, 16, 398-413. [CrossRef]

61. Lovreglio, R.; Leone, V.; Giaquinto, P.; Notarnicola, A. Wildfire cause analysis: Four case-studies in southern Italy. IFor. Biogeosci. For. 2010, 3. [CrossRef]

62. Gilless, J.K.; Fried, J.S. Stochastic representation of fire behavior in a wildland fire protection planning model for California. For. Sci. 1998, 454, 492-499.

63. Biasi, R.; Colantoni, A.; Ferrara, C.; Ranalli, F.; Salvati, L. In-between sprawl and fires: Long-term forest expansion and settlement dynamics at the wildland-urban interface in Rome, Italy. Int. J. Sustain. Dev. World Ecol. 2015, 22, 467-475. [CrossRef] 
64. Salvati, L.; Ferrara, A.; Mancino, G.; Kelly, C.; Chianucci, F.; Corona, P. A Multidimensional Statistical Framework to Explore Seasonal Profile, Severity and Land-Use Preferences of Wildfires in a Mediterranean Country. Int. For. Rev. 2015, 17, 485-497. [CrossRef]

65. Ferrara, C.; Carlucci, M.; Grigoriadis, E.; Corona, P.; Salvati, L. A comprehensive insight into the geography of forest cover in Italy: Exploring the importance of socioeconomic local contexts. For. Policy Econ. 2017, 75, 12-22. [CrossRef]

66. Stratton, R.D. Guidance on Spatial Wildland Fire Analysis: Models, Tools, and Techniques; Gen Tech Rep RMRS-GTR-183; U.S. Department of Agriculture, Forest Service: Fort Collins, CO, USA, 2006; Volume 183, 15p. [CrossRef]

67. Mavrakis, A.; Salvati, L. Analyzing the Behaviour of Selected Risk Indexes during the 2007 Greek Forest Fires. Int. J. Environ. Res. 2015, 9, 831-840.

(C) 2018 by the authors. Licensee MDPI, Basel, Switzerland. This article is an open access article distributed under the terms and conditions of the Creative Commons Attribution (CC BY) license (http:/ / creativecommons.org/licenses/by/4.0/). 